\title{
Comparative Study of Input Use, Productivity and Profitability of Hybrid and Traditional Rice Cultivation in Assam, India
}

\author{
Jeemoni Gogoi ${ }^{1 *}$, J.P. Hzaraika ${ }^{2}$ Utpal Barman ${ }^{3}$ and Nivedita Deka ${ }^{2}$ \\ ${ }^{1}$ Department of Agricultural Economics, CPGS-AS, Central Agricultural University (I), Umiam, Meghalaya, India \\ ${ }^{2}$ Department of Agricultural Economics, Assam Agricultural University, Jorhat, Assam, India \\ ${ }^{3}$ Department of Extension Education, Assam Agricultural University, Jorhat, Assam, India \\ *Corresponding author: jeemoni55555@gmail.com (ORCID ID: 0000-0001-7725-7160)
}

Received: 24-03-2020

Revised: $19-07-2020$

Accepted: 23-08-2020

\begin{abstract}
With the rising demand for food in India, hybrid rice plays a vital role in its high production. A research study was conducted in Assam, a northeastern state of India is purely agrarian in nature with major ricegrowing seasons Ahu (Autumn), Sali (Winter) and Boro (Summer) in the state. Hybrid rice in Boro season is getting momentum in the state because it is giving higher yield to the rice farmers than traditional rice varieties. The study was design to compare the economics of hybrid rice and traditional rice cultivation in Assam with total sample of 90, considering 60 hybrid rice grower and 30 traditional rice grower using cost concepts given by CACP. The result shows that the cost of cultivation of hybrid rice was higher than the traditional rice due to the higher cost of fertilizer, seed and labour. However, the yield of hybrid rice was much higher $\left(109.92 \mathrm{ql}^{\text {-ha }}\right)$ than the traditional rice $\left.\left(49.70 \mathrm{ql}^{\text {-ha }}\right)\right)$. Thus, the farmers obtained a higher return over cost from hybrid rice (2.30) than traditional rice (1.66). The finding has suggested the adoption of hybrid rice in the study area a profitable for farmers to have more income even with the higher cost of production.

\section{Highlights}

( Hybrid rice cultivation is more profitable to the rice-growing farmers than the traditional rice by employment generation and enhancing income.
\end{abstract}

Keywords: Hybrid rice, traditional rice, profitability, Assam

In Asia, rice consumed as staple food nearly for 50 percent of the populations, for South Asia alone the figure is about 70 percent (Bishwajit et al. 2013). In India, rice contributes about 40-43 percent of total food grain production from one-quarter of the total cropped area and play a vital role in the national food and livelihood security system (Krishniah and Shobha Rani, 2000). India is the largest exporter of rice in the world market since 2011 (Varma, 2017). Hybrid rice has the potential to transform rice cultivation in India (Spielman et al. 2014). Hybrid rice was identified as one of the components under the National Food Security Mission (NFSM) launched by the Government of India (GoI) during 2007-08 with the aim to enhance rice production of $10 \mathrm{MT}$ by 2011-12. The emphasis was also being given for the adoption of hybrid rice under the special scheme of GoI to Bringing Green Revolution to Eastern India (BGREI) (Virakatamath, 2011). During 1995 area under hybrid rice was 10,000 hectares which has reached one million ha in 2006 and exceeded 2.5 million hectares during 2014, which was about 5.6 percent of the total rice area in the country. The area was increasing in the last eleven years, mainly due to increasing popularity

How to cite this article: Gogoi, J., Hzaraika, J.P., Barman, U. and Deka, N. (2020). Comparative Study of Input Use, Productivity and Profitability of Hybrid and Traditional Rice Cultivation in Assam, India. Economic Affairs, 65(3): 389-394.

Source of Support: None; Conflict of Interest: None 
of hybrid rice and around 3 million ha area was estimated to be under hybrid rice cultivation in India in 2016 which was around 7 percent of the total rice cropped area (Vadlamani, 2016).

Rice occupies about two-thirds of the total cropped area in the state of Assam. Rice is considered to be a single major source of agricultural income and it plays a significant role in the state economy. The state is producing 5127 Th tonnes of rice during 2016-17 from a land area of 24.67 lakh ha with a productivity of $2078 \mathrm{~kg} / \mathrm{ha}$ which was below the national average rice yield $(2550 \mathrm{~kg} /$ ha) (Government of Assam, 2018). Hybrid rice was introduced in the state largely with the implementation of NFSM-Rice and BGREI program with the total area under hybrid rice was 1.60 lakh ha during 2016-17 which is only 6.5 percent of the rice area (Government of Assam, 2018). The study is in line with Awal et al. (2007) where they concluded that the hybrid performed better than conventional varieties of rice and Parvez et al. (2003) who reported that, gross return was 21 per cent higher in hybrid variety than the check variety thus contributing to a 5 per cent higher benefit-cost ratio.. Grain yield of hybrids was 14 percent higher than that of HYVs and input costs of hybrids were 23 per cent higher as reported by Husain et al. (2001). Regalado (2011) found that the average yield advantage of hybrid rice production over inbred was 8-14 per cent and net profit ratio was high in case of a hybrid than inbred rice. Wagan et al. (2015) revealed that the cost of production of hybrid was more than conventional varieties but the yield gained was higher in case of hybrid, therefore, higher profit was observed in hybrid rice than the conventional rice. Considering the growing importance of hybrid rice in the state and whether the farmers are getting profit from the hybrid rice, the present paper attempts to study the comparative economics of hybrid and traditional rice in the state of Assam. The objective is to assess the productivity and relative profitability of and hybrid rice and traditional rice production at the farmers' field.

\section{MATERIALS AND METHODS}

\section{Sampling design}

A multi stage random sampling design was used for the study. The sampling design consisted of three stages. In the first stage Nagaon district was purposively selected as the district has the highest area under hybrid rice (9547 ha) in Assam (District Agriculture Office, Nagaon, 2018). In the second stage, two blocks were selected from the district at random based on the number of farmers adopting hybrid rice cultivation. In the final stage, sixty farmers adopting both hybrid rice and traditional rice and thirty farmers adopting only traditional rice were selected from two blocks resulting in 90 sample respondents. In the study area farmers grow hybrid varieties ARIZE 6444, KRH 2, PAC 832, PAC 835, DRRH 1, ARIZE Gold etc and traditional rice varieties such as Ranjit, Mashuri, Swarna Sub-1, Gitesh, Bahadur. For the present study, the varieties considered for hybrid and traditional were ARIZE 6444 and Ranjit, respectively.

\section{Data}

Primary data were collected from the sample rice growers with the help of pre-tested schedule pertaining to the year 2017. The secondary data were collected from the Directorate of Economics and Statistics, Department of Agriculture and published as well as unpublished reports.

\section{Selection of farmer}

The farmers were categorized into three size groups by landholding size viz., marginal (less than 1 ha), small (1.01-2.00 ha) and medium (more than $2 \mathrm{ha}$ ). No large farmers were found in the selected sample (Table 1).

Table 1: Distribution of sample farms according to hybrid and traditional grower

\begin{tabular}{llll}
\hline Size Class & $\begin{array}{l}\text { No. of } \\
\text { Farmers }\end{array}$ & $\begin{array}{l}\text { Hybrid rice } \\
\text { grower }\end{array}$ & $\begin{array}{l}\text { Traditional } \\
\text { rice grower }\end{array}$ \\
\hline $\begin{array}{l}\text { Marginal (less } \\
\text { than 1 ha) }\end{array}$ & $40(44.44)$ & $25(27.77)$ & $15(16.66)$ \\
$\begin{array}{l}\text { Small (1.01-2.00 } \\
\text { ha) }\end{array}$ & $26(28.89)$ & $17(18.88)$ & $9(10.00)$ \\
$\begin{array}{l}\text { Medium (2.01- } \\
10.00 \text { ha) }\end{array}$ & $24(26.67)$ & $18(20.00)$ & $6(6.66)$ \\
\hline Total & $\mathbf{9 0 ~ ( 1 0 0 . 0 0 )}$ & $\mathbf{6 0 ( 6 6 . 6 6 )}$ & $\mathbf{3 0 ( 3 3 . 3 3 )}$ \\
\hline
\end{tabular}

Figures in the parentheses indicate percentage to total number of farmers

Source: Field survey 2017 


\section{Methodology}

The cost of production and return was calculated as per the cost concept given by CACP (Commission of Agricultural Cost and Price). The cost, returns and profitability of this study were shown with the help of tabular analysis. The land revenue considered under the cost of cultivation was ₹ 5/bigha and 1 hectare is equal to 7.5 bigha which gives a total to 37.5 per hectare.

The return was considered in terms of:

Gross income $(G I)=(Q m \times P m)+(Q b \times P b)$

Where:

$$
\begin{aligned}
& G I=\text { Gross income } \\
& Q m=\text { Quantity of main product } \\
& P m=\text { Price of the main product } \\
& Q b=\text { Quantity of by-product } \\
& P b=\text { Price of by- product }
\end{aligned}
$$

Return over total cost $=\frac{\text { Gross return }}{\text { Total cost }}$

\section{RESULTS AND DISCUSSION}

The results obtained were presented according to farm size as well as average for the comparison of cost of cultivation and return for hybrid rice and traditional rice.

\section{Comparison of economics of rice cultivation hybrid and traditional method}

Table 2 represents the comparison of cost structures incurred by both hybrid and traditional rice systems. Under hybrid rice cultivation, the total cost involved was the highest for a medium farm with ₹ 72155.19, followed by small and marginal with ₹ 62656.11 and ₹ 62038 with an average total cost of ₹ 65248.48. Similarly under traditional rice, the total cost of cultivation for different farm size groups were ₹ 42734.27, ₹ 47193.18 and ₹ 52612.20 for marginal, small and medium farmers, respectively and average was ₹ 46047.53. The total cost of cultivation was higher for hybrid rice than that of traditional rice for different size group of farmers and for overall size group as well. Human labour cost accounted for the highest share to the total cost (41.35 per cent for hybrid and 37.46 per cent for traditional rice, respectively). Similar research studies was carried out in the Indian states of Andhra Pradesh, Karnataka and West Bengal showed that on an average, labour accounted for about 48 percent of the total cost under hybrid rice production (Janaiah and Hossain, 2000). Studies shows that human labour cost has the highest share of rice cultivation, reported by Devi and Ponnarasi (2009). Our findings are well supported by Chengappa et al. (2003) where it was

Table 2: Comparative economics of hybrid and traditional rice cultivation ( $₹ / h a)$

\begin{tabular}{lllllllll}
\hline \multirow{2}{*}{ Particulars } & \multicolumn{3}{c}{ Marginal } & \multicolumn{2}{c}{ Small } & \multicolumn{2}{c}{ Medium } & \multicolumn{2}{c}{ All farms } \\
\cline { 2 - 8 } & Hybrid & Traditional & Hybrid & Traditional Hybrid & Traditional Hybrid & Traditional \\
\hline Human Labour (mandays) & 25440.00 & 15214.10 & 25424.58 & 17962.00 & 30591.57 & 21271.10 & 26981.10 & 17249.87 \\
$\quad$ i. Hired labour (mandays) & 17925.00 & 9654.05 & 19014.12 & 12587.00 & 24217.00 & 16278.60 & 20121.18 & 11858.85 \\
$\quad$ ii. Family labour (mandays) & 7515.00 & 5560.05 & 6410.46 & 5375.00 & 6374.57 & 4992.50 & 6859.92 & 5391.03 \\
Machine labour (machine hour) & 7000.00 & 6500.00 & 7000.00 & 6500.00 & 7000.00 & 6500.00 & 7000.00 & 6500.00 \\
Seed (kg) & 2457.60 & 913.50 & 2578.82 & 982.50 & 2702.22 & 1012.50 & 2565.33 & 954.00 \\
Farm Yard Manure (ql) & 860.00 & 333.33 & 906.00 & 372.22 & 989.00 & 458.33 & 911.73 & 370.00 \\
Fertilizer (kg) & 2166.85 & 1027.50 & 2750.64 & 1336.33 & 3468.00 & 1503.55 & 2722.60 & 1215.36 \\
Plant protection chemicals (gm) & 1013.69 & 161.61 & 1338.27 & 201.10 & 1515.00 & 228.33 & 1256.05 & 186.80 \\
Irrigation Charges (hours) & 2073.25 & 726.88 & 2565.00 & 987.77 & 2754.50 & 1146.54 & 2416.95 & 889.08 \\
Interest on working capital & 2050.57 & 1243.85 & 2128.17 & 1417.10 & 2451.01 & 1606.02 & 2192.69 & 1368.26 \\
@10\% for 6 months & & & & & & & & \\
Total variable cost & 43061.96 & 26120.77 & 44691.48 & 29759.02 & 51471.30 & 33726.37 & 46046.46 & 28733.36 \\
Depreciation @10\% & 831 & 456 & 795.88 & 630 & 1257.5 & 1065 & 949 & 630 \\
Land revenue & 37.5 & 37.5 & 37.5 & 37.5 & 37.5 & 37.5 & 37.5 & 37.5 \\
Rental Value of owned land & 15000 & 15000 & 15000 & 15000 & 15000 & 15000 & 15000 & 15000 \\
Interest on fixed capital@10\% & 3108 & 1120 & 2131.25 & 1766.66 & 4388.89 & 2783.33 & 3215.52 & 1646.66 \\
Total fixed cost & 18976.50 & 16613.50 & 17964.63 & 17434.16 & 20683.89 & 18885.83 & 19202.02 & 17314.16 \\
Total cost & 62038.46 & 42734.27 & 62656.11 & 47193.18 & 72155.19 & 52612.20 & 65248.48 & 46047.53 \\
\hline
\end{tabular}

Source: Field survey 2017. 
mentioned that among the components of total cost, expenditure on labour formed the single largest item and accounted for 43.11 per cent and 40.84 per cent of the total cost for hybrid and traditional varieties, respectively.

The comparative cost analysis between hybrid and traditional rice cultivation per hectare showed that there was increase in cost for hybrid rice over traditional rice cultivation for all the costs components. On an average, hybrid rice cultivation had 29.43 percent higher total cost than that of traditional rice. The highest increase in cost for hybrid rice over traditional was recorded for plant protection chemicals (85.13 percent) followed by irrigation cost (63.21 percent) and seed cost (62.81 percent). Under traditional rice cultivation, farmers used very nominal amount of plant protection chemical that resulted in the highest change in cost in hybrid rice over traditional rice (Table 3).

\section{Comparison of income level under hybrid and traditional rice cultivation}

Table 4 depicted various income levels both under hybrid and traditional rice cultivation. Under hybrid rice, the yield of main product was found to be $98.46 \mathrm{ql} /$ ha for marginal, $106.76 \mathrm{ql} / \mathrm{ha}$ for small and $115.50 \mathrm{ql} / \mathrm{ha}$ for medium size group farmers. Under traditional rice, the yield of main product was 44.90 $\mathrm{ql} /$ ha for marginal, $52.50 \mathrm{ql} /$ ha for small and $57.50 \mathrm{ql} /$ ha for medium size group farmers with this overall yield of hybrid rice was found double (105.92 ql/ ha) than the traditional rice (49.70ql/ha). Abdus et al. (2011) reported that an average yield of $77.57 \mathrm{ql} /$ ha of hybrid rice against an average yield of 60.27 $\mathrm{ql} / \mathrm{ha}$ of inbred rice in Bangladesh indicating that hybrid rice out yielded inbred rice by 29 percent. In the study area, on an average, the gross return, net return and return over cost were higher for hybrid rice ( $₹ 150232.58 /$ ha, $76282.33 /$ ha and 2.30 ) than that in traditional rice (₹ 76220/ha, ₹ 24097.46/ ha and 1.66). Our findings shows that hybrid rice cultivation had 53.08 percent yield advantage from the main product and 12.33 percent yield advantage from by-product in comparison to traditional rice. A similar finding was reported by Sarkar (2013) that the net return from the hybrid rice was found to be 48.36 percent and 58.30 percent more as compared to traditional rice in the field of hybrid rice adopter and non-adopter farms. The return over total cost

Table 3: Percentage-wise comparison of cost of cultivation of hybrid rice and traditional rice cultivation (₹/ha)

\begin{tabular}{|c|c|c|c|c|c|}
\hline \multirow[b]{2}{*}{ Particulars } & \multicolumn{2}{|c|}{ Hybrid rice } & \multicolumn{2}{|c|}{ Traditional rice } & \multirow{2}{*}{$\begin{array}{l}\text { - \% change of hybrid rice } \\
\text { over traditional rice }\end{array}$} \\
\hline & Cost & $\begin{array}{l}\% \text { to total } \\
\text { cost }\end{array}$ & Cost & $\begin{array}{l}\% \text { to total } \\
\text { cost }\end{array}$ & \\
\hline Family labour(mandays) & 20121.18 & 30.84 & 11858.85 & 25.75 & 41.06 \\
\hline Hired labour(mandays) & 6859.92 & 10.51 & 5391.03 & 11.71 & 21.41 \\
\hline Farm Yard Manure (ql) & 911.73 & 1.40 & 370 & 0.80 & 59.42 \\
\hline Fertilizer (kg) & 2722.6 & 4.17 & 1215.36 & 2.64 & 55.36 \\
\hline Plant protection chemicals (gm) & 1256.05 & 1.93 & 186.8 & 0.41 & 85.13 \\
\hline Irrigation Charges (hours) & 2416.95 & 3.70 & 889.08 & 1.93 & 63.21 \\
\hline Depreciation@10\% & 949 & 1.45 & 630 & 1.37 & 33.61 \\
\hline Land revenue & 37.5 & 0.06 & 37.5 & 0.08 & 0.00 \\
\hline Rental Value of owned land & 15000 & 22.99 & 15000 & 32.58 & 0.00 \\
\hline Interest on fixed capital @10\% & 3215.52 & 4.93 & 1646.66 & 3.58 & 48.79 \\
\hline Total fixed cost & 19202.02 & 29.43 & 17314.16 & 37.60 & 9.83 \\
\hline Total cost & 65248.48 & 100.00 & 46047.53 & 100.00 & 29.43 \\
\hline
\end{tabular}

Source: Field survey 2017. 
Table 4: Comparative return from hybrid and traditional rice $(₹ / h a)$

\begin{tabular}{|c|c|c|c|c|c|c|c|c|c|}
\hline \multirow[b]{2}{*}{ Particulars } & \multicolumn{2}{|l|}{ Marginal } & \multicolumn{2}{|l|}{ Small } & \multicolumn{2}{|l|}{ Medium } & \multicolumn{2}{|l|}{ All farms } & \multirow{2}{*}{$\begin{array}{l}\text { \% change in } \\
\text { hybrid rice } \\
\text { over Tradi- } \\
\text { tional rice }\end{array}$} \\
\hline & Hybrid & $\begin{array}{l}\text { Tradi- } \\
\text { tional }\end{array}$ & Hybrid & $\begin{array}{l}\text { Tradi- } \\
\text { tional }\end{array}$ & Hybrid & $\begin{array}{l}\text { Tradi- } \\
\text { tional }\end{array}$ & Hybrid & $\begin{array}{l}\text { Tradi- } \\
\text { tional }\end{array}$ & \\
\hline $\begin{array}{l}\text { Yield of the main product } \\
\text { (q1/ha) }\end{array}$ & 98.46 & 44.90 & 106.76 & 52.50 & 115.50 & 57.50 & 105.92 & 49.70 & 53.08 \\
\hline $\begin{array}{l}\text { Yield of the by-product (q1/ } \\
\text { ha) }\end{array}$ & 17.91 & 15 & 19.56 & 18 & 21.30 & 19 & 19.39 & 17 & 12.33 \\
\hline Price of main product (₹/ql) & 1400 & 1500 & 1400 & 1500 & 1400 & 1500 & 1400 & 1500 & -7.14 \\
\hline Price of by product (₹/ql) & 100 & 100 & 100 & 100 & 100 & 100 & 100 & 100 & 0.00 \\
\hline $\begin{array}{l}\text { Return from main product } \\
(₹ / \mathrm{ha})\end{array}$ & 137844 & 67350.00 & 149464 & 78750.00 & 161700 & 86250.00 & 148293.13 & 74550.00 & 49.73 \\
\hline $\begin{array}{l}\text { Return from the by-product } \\
\text { (₹/ha) }\end{array}$ & 1791.00 & 1500.00 & 1956.00 & 1800.00 & 2130.00 & 1900.00 & 1939.45 & 1670.00 & 13.89 \\
\hline Gross return (₹/ha) & 139635.00 & 68850.00 & 151420.00 & 80550.00 & 163830.00 & 88150.00 & 150232.58 & 76220.00 & 49.27 \\
\hline Net return (₹/ha) & 68686.55 & 19365.73 & 77904.49 & 27231.79 & 85300.01 & 31225.29 & 76282.33 & 24097.46 & 68.41 \\
\hline Return over cost & 2.25 & 1.61 & 2.42 & 1.71 & 2.27 & 1.68 & 2.30 & 1.66 & 27.83 \\
\hline
\end{tabular}

Source: Field survey 2017.

was found to be 27.83 percent higher in hybrid rice which indicated that hybrid rice was more remunerative to farmers of the study area. Memon et al. (2015) revealed in their study that, total costs per acre of hybrid rice were slightly high due to higher hybrid seed prices, slightly higher land management costs but the higher yield was obtained from hybrid rice and which further indicated that hybrid rice growers obtained higher gross margin giving additional income to deprived farmers. The $\mathrm{B}: \mathrm{C}$ ratio of basmati rice was 1.20 and that of hybrid rice was 1.80 , indicating profitability of hybrid rice that has brought comparatively more economic benefits to the farmers as compared to basmati reported by Saeed et al. (2013).

Cost of cultivation of hybrid rice over traditional rice was higher considering the seed cost and increased use of other inputs such as plant protection chemicals. In the study area, the total cost of cultivation of hybrid rice was ₹ 65248.48/ha which was higher than the total cost of cultivation of inbred rice (₹ $46047.53 /$ ha). Similarly, the cost of hybrid rice was high followed by the inbred varieties as reported by Khushik et al. (2011). Prakash et al. (2017) in their study on comparative analysis on the economic efficiency of hybrid and traditional rice production reported that total cost of cultivation per hectare for hybrid and rice was ₹ 46301.06 and ₹ 40761.47, respectively. It was further observed that for both the types, cost of cultivation had increased with an increase in farm size which might be due to the use of more inputs by the larger farm size groups. As a whole, there was 37.60 per cent increase in variable cost for hybrid rice cultivation over traditional rice cultivation while, for a fixed cost, it was 9.83 per cent more in hybrid rice over inbred rice. The return from hybrid rice cultivation was higher than traditional rice cultivation due to the higher productivity of hybrid rice over traditional rice. However, no definite relationship between farm size and productivity could be observed in both types of rice varieties. Though the price per quintal of hybrid rice (₹ 1400/ql) was less than traditional rice (₹ 1500/ql), due to its higher production, the gross return and net return from hybrid rice was 49.27 per cent and 68.41 per cent higher than traditional rice. The yield advantage was found to be 53.08 per cent in hybrid over traditional rice giving to a higher benefit cost ratio. The farmers in the study area have taken much care of the hybrid rice fields considering high investment compared to traditional rice fields.

\section{CONCLUSION}

With the expansion of area under rice in Assam which has already been exhausted, the only way to enhance profitability in rice cultivation is through modern technology. The study concludes that despite the higher cost of cultivation, hybrid rice gives higher yield (53.08 per cent) resulted in more net return to the farmers of the study area 
compared to traditional variety. Therefore, hybrid rice may be a potential technology to increase the average productivity level of rice in the state. Encouraging rural educated youth to take up modern technology like this would be a viable option for development in this sector, which in turn will benefit to sustain the food security along with the economic profitability. Proper policy measures need to be taken up to strengthen the sector for higher production from both the public as well as private sector of the country.

\section{REFERENCES}

Abdus, S.M., Parvin, J., Siddique, A.B., Islam, S.and Manir, M.R. 2011. Comparative Study on Economic Assessment of Inbred (HYVs) and Hybrid Rice Production: Evidences from the Farm Level Survey, International Journal of Robotics Research, 10: 1-7.

Awal, M.A., Habib, A.K.M.A. and Hussain, M.A. 2007. A Study On Comparative Performances Of Hybrid And Convntial Rice Varieties In Aman Season. Journal of Agriculture and Rural Development, 5(1\&2): 13-16.

Bishwajit, G., Sarker, S., Kpoghomou, M.A., Gao, H., Jun, L., Yin, D. and Ghosh, S. 2013. Self-sufficiency in rice and food security: a South Asian perspective. Agriculture $\mathcal{E}$ Food Security, 2(1): 10.

Chengappa, P.G., Janaiah, A. and Gowda, M.S. 2003. Profitability of Hybrid Rice Cultivation: Evidence from Karnataka, Economic and Political Weekly, pp. 2531-2534.

Devi, K.S. and Ponnarasi, T. 2009. An economic analysis of modern rice production technology and its adoption behaviour in Tamil Nadu, Agricultural Economics Research Review, 22(conf), 341.

District Agricultural Office, Nagaon. 2018. Department of Agriculture. Government of Assam.

Government of Assam. 2018. Economic Survey of Assam 201718. Directorate of Economics and Statistics. Government of Assam.

Husain, A.M., Hossain, M. and Janaiah, A. 2001. Hybrid rice adoption in Bangladesh: a socioeconomic assessment of farmers' experiences. Dhaka: Research and Evaluation Division, BRAC.

Janaiah, A. and Hossain, M. 2000. Hybrid rice for food security in the tropics: An evaluation of farm-level experiences in India. In $3^{\text {rd }}$ International Crop Science Congress held in Hamburg, Germany, pp. 17-22.

Khushik, A.M., Lashari, M.I. and Memon, A. 2011. Performance of Rice Hybrid and other varieties in Sindh and Balochistan, Journal of Agricultural Research, 49.
Krishniah, K. and Rani, N.S. 2000. New avenues for augmenting and sustaining rice exports from India, International Rice Commission Newsletter, 49: 42-51.

Memon, Q.U.A., Wagan, S.A., Wagan, T.A., Memon, I.H., Wagan, Z.A., Memon, H. and Memon, A.H. 2015. Economic Analysis of Hybrid Rice in Taluka Golarchi District Baddin Sindh, Pakistan, International Journal of Business and Economics Research, 4: 250-255.

Parvez, M.M., Harun-Ar-Rashid M., Parvez, S.S. and Islam, M.T. 2003. Performance of hybrid rice in Bangladesh: A comparative study. Japanese Journal of Tropical Agriculture, 47(3): 215-221.

Prakash, A., Singh, H.N., Shekhawat, R.S. and Sandu, S. 2017. Comparative Analysis on Economic Efficiency of Hybrid and Inbred Rice Production in Udham Singh Nagar District of Uttarakhand, Journal of Economics, Management and Trade, 18: 1-7.

Regalado, M.J.C. 2011. Proceeding of Regional Seminar on Rice Production and Mechanization held on 12-13 ${ }^{\text {th }}$ December in Sanya, China.

Saeed, R., Bashir, A., Qasim, M., Mehmood, I. and Bakhsh, K. 2013. Does Productivity Matter in the Adoption of Hybrid Rice? A Comparative Study, European Journal of Business and Economics, 8.

Sarkar, D. 2013. Spread of new varieties of hybrid rice and their impact on the overall production and productivity in Madhya Pradesh. AERC, Jawaharlal Nehru Krishi Viswa Vidyalaya, Jabalpur (MP).

Spielman, D.J., Ward, P.S. and Kolady, D.E. 2014. The Economics of Hybrid Rice in Asia: Technology Adoption, Public Expenditures and Private Incentives. Hybrid rice development in Asia: Assessment of Limitations and Potential, 2-3.

Vadlamani, R. 2016. Hybrid rice in India-2016-Status. https:// www.linkedin.com/pulse/hybrid-rice-india-2016-statusraja-vadlamani

Varma, P. 2017. An Overview of Rice Economy. In : Rice Productivity and Food Security in India. Springer, Singapore, 28.

Viraktamath, B.C. 2011. Hybrid rice in India-current status and future prospects. Rice Knowledge Management Portal (RKMP), Directorate of Rice Research, Hyderabad, India.

Wagan, S.A., Noonari, S.M., Memon, I.N., Bhatti, M.A., Kalwar, G.Y., Sethar, A.A. and Jamro, A.S. 2015. Comparative Economic Analysis of Hybrid Rice v/s Conventional Rice Production in District Badin Sindh Province Pakistan. Journal of Environment and Earth Science, 5(3): 76-89. 